\title{
TECHNOLOGIES FOR TRAINING SPECIALISTS IN THE HOTEL AND CATERING INDUSTRY IN UKRAINE IN THE CONTEXT OF LIFELONG LEARNING
}

\author{
Iana E. ANDRIUSHCHENKO* \\ Mykolaiv National Agrarian University, Faculty of Management, Department of Hotel and Restaurant \\ Business and Business Organization, Mykolaiv, Ukraine, e-mail: andriushchenko6785@tanu.pro
}

Tetiana Ya. IVANENKO

Mykolaiv National Agrarian University, Faculty of Management, Department of Hotel and Restaurant Business and Business Organization, Mykolaiv, Ukraine, e-mail: t.ivanenko@nuos.pro

\section{Valentina H. BURAK}

Kherson State University, Faculty of Business and Law, Department of Hotel and Restaurant and Tourist Business, Kherson, Ukraine, e-mail: vh-burak@ust-hk.com.cn

\section{Ganna V. KOVALENKO}

Mykolaiv National Agrarian University, Faculty of Management,

Department of Enterprise Economics, Mykolaiv, Ukraine, e-mail: gkovalenko@ tanu.pro

Olena V. ZAMFERESKO

Lviv Higher Profession School of the Trade and Service Sphere, Lviv, Ukraine, e-mail: olena.z@uohk.com.cn

\begin{abstract}
Citation: Andriushchenko, I.E., Ivanenko, T.Y., Burak, V.H., Kovalenko, G.V., \& Zamferesko, O.V. (2021). TECHNOLOGIES FOR TRAINING SPECIALISTS IN THE HOTEL AND CATERING INDUSTRY IN UKRAINE IN THE CONTEXT OF LIFELONG LEARNING. GeoJournal of Tourism and Geosites, 37(3), 838-843. https://doi.org/10.30892/gtg.37314-716
\end{abstract}

\begin{abstract}
This article is relevant, as staff training in the context of lifelong learning increases the value of travel services for customers, providing added value in the hotel and catering industry. The purpose of the paper is to study the technologies of training specialists in the hotel and catering industry in the context of lifelong learning for the formation of the life cycle of an employee in the hospitality industry. The research methodology is based on statistical analysis of indicators for distribution. The results demonstrate that there are differences in the technologies for training specialists in the hospitality industry in terms of such characteristics, as: the provider of educational services, the initial educational level, the position held by the specialist and the status in the society. The practical value of the research lies in the possibility of using the existing methodology of the life cycle of training a specialist in the practice of hotel and catering industry.
\end{abstract}

Key words: management, hospitality, staff, customer, educational services, work experience, professional skills

$* \quad * \quad * \quad * \quad * \quad *$

\section{INTRODUCTION}

According to the analytical centers of the International Hotel and Restaurant Association, the success of the hotel and catering industry in the XXI century depends on the integration of technologies in order to meet the needs of customers of travel services on their terms (Olsen and Connolly, 2000). This involves taking into account the desires and needs of customers, instant provision of information about services at the request of customers. In addition, highly trained staff in the context of the perfect use of technology will increase the value of travel services for customers, providing added value in the field of hotel and catering industry. In this context, it is advisable to explore effective tools for the training professionals of the hotel and catering industry, taking into account the rapid variability of new technologies. It is the variability that determines the constant systemic need for constant maintenance of staff knowledge, and, therefore, the need for education and lifelong learning. With the intensification of globalization processes, the tourism industry due to rapid growth has become one of the priority areas in the world economy, which affects both the development of individual industries and the socio-economic development of entire countries. According to the International Tourism Organization, the share of tourism in world GDP is $9 \%$, in world exports of services - 30\%, the share of world trade - $6 \%$, every 11 employees work in tourism (El-Said et al., 2020). Globalization poses new challenges to education. Thus, the growth of tourist flows in Europe implies the existence of uniform professional qualifications for tourism in all member states of the European Union (Brahami, 2020). That is knowledge of the language, culture, economy, the legal system of the partner countries, observance of uniform technological and humanitarian norms. Given Ukraine's desire to join the European Union, the content of national vocational tourism education must meet the needs of European countries. This is ensured by

\footnotetext{
* Corresponding author
} 
the corporatism of professional tourism education when in the process of training future corporate connections are formed (technological standards of hotel and tourist chains, franchise relations, licensing and certification standards, etc.).

Today in Ukraine more than 90 higher educational establishments and more than 100 professional establishments of the lower level of accreditation are engaged in the training of specialists in the field of tourism (Osypova, 2020). This contributes to the development of the tourism industry, but the low degree of cooperation between vocational tourism education institutions and enterprises does not allow for the formation of high-quality theoretical and practical aspects of education. Tourism education in Ukraine today acquires special significance. Holding various thematic exhibitions, tourist salons, fairs, signing agreements with regional state administrations on training and retraining of tourism and hospitality professionals for the regions - all this contributed to the promotion of new specialties and involvement of interested young people in tourism (Frash et al., 2010). The realities of the process of training tourism professionals often show that theoretical training in Ukraine is mostly carried out properly and sufficiently covers a variety of necessary disciplines and subjects. But during the internship, a large number of tourism companies do not want to spend their time on internships for students or use their internships as free labour for small assignments, which later has a negative impact on practical training. Basic training of hotel and catering industry's professionals in the context of lifelong learning should be of a high priority for economic entities (Jaswal, 2020); it should develop practical skills of professionals in the context of professional development strategy. "Effective training is especially important for modern restaurants that aim to gain competitive advantage by means of good quality service and performance of their employees" (Ballesteros-Rodríguez et al., 2012: 3226). Therefore, the development of personnel skills in the hospitality industry becomes a challenge for public policy at the national level with a focus on training as a training technology (Baum, 2002). The advantages of specialists in the hotel and catering industry, but also the disadvantages and variability of efficiency are being discussed in the scientific literature (Clarke, 2002; Frash et al., 2010). The low quality of training services due to inappropriate materials is among the disadvantages (Holton et al., 2000). Another problem is the discrepancy between the expectations of professionals and the experience of training or taking courses, which has been revealed in the study of joint training of British programs for the provision of education in tourism sphere (Leslie and Richardson, 2000).

Unstructured internship negatively affects the choice of profession by graduates of the hotel and catering industry. Therefore, the search for a balance between theory and practice within the curriculum in the field of hospitality is performed. The redundancy of using a pragmatic approach in some educational institutions has been revealed; it reduces the level of critical thinking of specialists (Brahami, 2020). The lack of understanding and rejection by teachers of changes in the external environment is among the shortcomings of training technologies; it leads to the lack of balance between theory and practice (Tse, 2012). In the study of King and Qiu (2017), the indications of alternative approaches to "experiential learning" technologies have been suggested, namely: internships in training hotels, aligning students' learning outcomes with experience-based subjects and curriculum. Practice in the hotel and catering industry should be fully integrated into the curriculum (Tse, 2012). "Lifelong learning is more essential than ever before in today's global, high technology knowledge economy" (Koo et al., 2019: 113). Companies expect development and training from employees, but staff support in this area depends on the value of training that companies see. It is difficult to integrate the concept of lifelong learning in the field of hospitality (Rakicevik et al., 2008). This is due to differences in the training needs of both: interested parties - employers and staff. Another reason for slow integration is the legal framework, which does not address the issue of lifelong learning, especially in developing countries. Herewith, short-term trainings and informal courses are becoming increasingly popular. Financial costs are important; they often do not provide an effect through staff turnover in the hospitality industry (Rakicevik et al., 2008). In the scientific literature, the concept of "a continuous learning culture" and "effective training" has been formed in the hospitality industry, the mediator between which is the practice of human resource management (Ballesteros-Rodríguez et al., 2012). Effective training provides a reduction in staff turnover, forasmuch as employees estimate a higher level of job satisfaction. As a result, professionals better serve customers, ensuring a stable profit for the company. This provides a win-win situation for all interested parties in the hotel company (Kalargyrou and Woods, 2011). Leaders of hotel and catering industry provide staff training (Frash et al., 2010).

With the support of educational and training institutions, the skills of specialists for lifelong learning are being updated. The need for quality customer service is one of the motives for investing in education (Frash et al., 2010; Scerri et al., 2020). Higher educational institutions increase the level of employment of hospitality industry's graduates by integrating theoretical knowledge in the field of hotel and catering industry management and practical skills in this field (Ruhanen, 2006). "Training hotels" are among the institutions providing lifelong learning; they form a specialized environment of common hallmarks of business operations in the hospitality industry and the practice of providing high quality services.

\section{MATERIALS AND METHODS}

This research is based on a qualitative and quantitative methodology for the study of technologies for training specialists in the hotel and catering industry in the context of lifelong education in order to form the life cycle of a specialist (Figure 1). Based on data on the distribution of non-formal education and training activities by provider in EU in 20072016 and International Standard Classification of Education the distribution of education and training activities by field in EU in $2016(\%)$, the basic trends in the field of training within EU have been identified. A quantitative analysis has been conducted on the basis of indicators on the number of vacancies posted for the last 30 days and a summary for the last three months. The main criteria for identifying trends in the training of specialists in the hotel and catering industry are as follows: average salary; requirements for the level of remuneration of candidates; position, work experience, knowledge of foreign languages, level of education, professional skills, previous place of work (Osypova, 2020). 
In order to identify trends in the technology of training specialists in the field of hospitality, a content analysis of 120 resumes on the level of remuneration and position has been carried out, posted on the job search site Work.ua. The analysis of the resumes was carried out by systematizing the basic categories of staff depending on the level of remuneration, namely: management and top management, middle managers, lower-level specialists. Hotels, managed and owned by educational institutions, have more opportunities to implement training based on a practical approach. The study of King and Tang (2020) proves that hotels define their mission of training and preparing students for practical activities, and the learning process is included in the provision of services. Students' mentoring, participation of practitioners in students' education, various internship programs, research programs are integrated in training hotels (Tse, 2012). These training technologies solve the problems of providing quality education in the field of hospitality, namely: lack of innovation, negative practice of students' internships. Training hotels are also focused on receiving income from the provision of educational services and training (Scerri et al., 2020). This limits the opportunities for trainees to undergo practice at the hotel. Such hotels include international chains and brands. The viability of training hotels depends on a growing number of positive customers' reviews. Technology and social networking provide instant feedback on staff performance. Thus, the approach to the formation of technology for training specialists should take into account both the financial side of the functioning of educational institutions, training hotels, and positive feedback from customers about high standards of service. Learning technologies should take into account the experimental approach to curricula, courses and trainings.

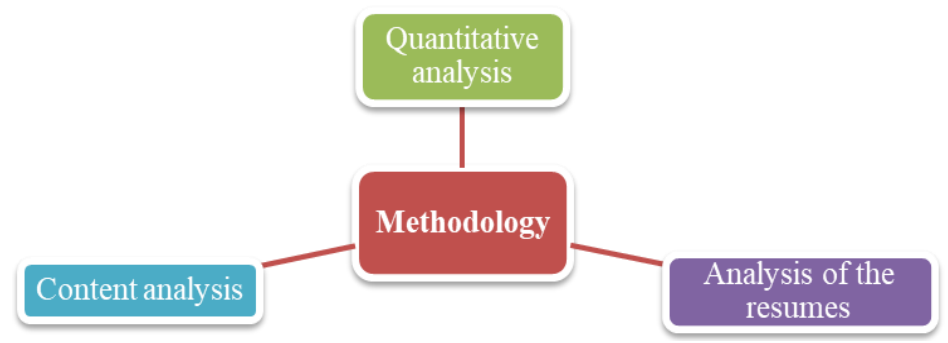

Table 1. Distribution of non-formal education and training activities by provider in EU (Source: Eurostat,

\begin{tabular}{|l|l|l|l|c|}
\hline $\begin{array}{l}\text { European Union - 27 } \\
\text { countries (from 2020) }\end{array}$ & 2007 & 2011 & 2016 & $\begin{array}{c}\text { Growth, } \\
\%\end{array}$ \\
\hline $\begin{array}{l}\text { Formal education and } \\
\text { training institutions }\end{array}$ & 10.3 & 10.4 & 7.8 & -2.5 \\
\hline $\begin{array}{l}\text { Non-formal education } \\
\text { and training institutions }\end{array}$ & 17.5 & 18.1 & 19.3 & 1.8 \\
\hline $\begin{array}{l}\text { Commercial institutions } \\
\text { where education and } \\
\text { training is not the main } \\
\text { activity (e.g., equipment } \\
\text { suppliers) }\end{array}$ & 9.9 & 11.6 & 9.6 & -0.3 \\
\hline $\begin{array}{l}\text { Non-commercial } \\
\text { institutions where } \\
\text { education and training } \\
\text { are not the main activity } \\
\text { (e.g., libraries, } \\
\text { museums, ministries) }\end{array}$ & 4.8 & 5.9 & 3.7 & -1.1 \\
\hline Employer & 36.8 & 31.2 & 33.7 & -3.1 \\
\hline $\begin{array}{l}\text { Employers' } \\
\text { organizations, chambers } \\
\text { of commerce }\end{array}$ & 4.8 & 3.0 & 4.5 & -0.3 \\
\hline Trade unions & 1.6 & 1.1 & 1.2 & -0.4 \\
\hline $\begin{array}{l}\text { Non-profit associations } \\
\text { (e.g., cultural society, } \\
\text { political party) }\end{array}$ & 4.5 & 6.2 & 7.2 & 2.7 \\
\hline $\begin{array}{l}\text { Individuals (e.g., students, } \\
\text { giving private lessons) }\end{array}$ & 4.2 & 5.2 & 5.8 & 1.6 \\
\hline Other training providers & 3.9 & 5.2 & 5.1 & 1.2 \\
\hline
\end{tabular}

\section{RESULTS AND DISCUSSION}

The technologies for training specialists in the hotel and catering industry in the context of lifelong learning differ significantly within EU countries. In particular, there are differences in such characteristics, as: the provider of educational services, the initial level of education, the position held by the specialist and the status in society. Employers most often provide staff with training programs and other forms of non-formal education within EU, which is 33,7\% (Table 1). Next ones, according to the share of provision of non-formal educational services and trainings, are non-formal educational and training institutions (19.3\%), commercial institutions where education and training is not the main activity (e.g., equipment suppliers) (9.6\%) and formal education and training institutions (7.8\%). Non-profit associations (e.g., cultural society, political party) ensure the provision of $7.2 \%$ of non-formal educational services, individuals (e.g., students, giving private lessons) - 5.8\%. Within EU, the share of educational and training activities varies significantly from country to country (Table 2). For instance, in EU, the average rate of formal educational activities in the service sector was $6.8 \%$, the rate of non-formal educational activities was $22.3 \%$ and the rate of work-related activities was $19.5 \%$, the rate of non-work-related activities was $33.9 \%$. Non-formal education is the main method and form of acquiring new knowledge, which prevails in all EU countries. Herewith, the share of non-formal education prevails in less developed countries, compared to advanced countries (the Czech Republic, Hungary, Romania, and Turkey). Non-formal education that is not related to work in the service sector accounts for the largest share, especially in advanced countries (Germany, France, Poland). However, this trend is observed in 
developing countries (Hungary, Romania, Slovenia). Exceptions are the Czech Republic, Spain and Turkey. In Ukraine, students in the hotel and catering industry face the problem of hiring because of the absence of experience.

According to Osypova (2020), in a month 662 offers (vacancies) in this field of activity have been posted throughout Ukraine, accounting for $26.43 \%$ of the total number of vacancies (2505). Herewith, 773 vacancies are offered to inexperienced candidates $(30.68 \%)$. Over the past three months, 26609 resumes have been posted in Ukraine in the category "Hotel and catering industry, tourism", which means a significant excess of supply over demand and high competition for 1 job place. This increases the requirements for employees, their skills, qualifications and knowledge.

The average salary in the category "Hotel and catering industry, tourism" in Ukraine is 11 thousand UAH, while wages vary depending on the position (Figure 2). For comparison, the average level of wage requirements from candidates significantly exceeds the supply of employers, in particular, in management and leadership positions. Consequently, $6.41 \%$ of candidates in the resume indicate a salary of 15 thousand $\mathrm{UAH} / \mathrm{month}$, and $7.41 \%$ - from 10 thousand $\mathrm{UAH} / \mathrm{month}$.

The technologies for training specialists in the hotel and catering industry in Ukraine in the context of lifelong education differ significantly depending on the position, work experience, knowledge of foreign languages, education, professional skills. However, the determining conditions for lifelong learning in this area are the level of education, previous job and experience, position. It is these characteristics that determine the ability to train a specialist throughout life. Among the posted resumes, 6430 candidates possess higher education, 7682 - unfinished higher, 8357 - vocational secondary, 2953 - secondary education. Among the candidates, 6782 have no work experience, 4533 have up to 1 year of experience, 3710 - from 1 to 2 years of experience, 6057 - from 2 to 5 years of experience, 5528 - over 5 years of experience. According to these characteristics, it is advisable to determine the profiles of candidates for specialists in the hotel and catering industry in the context of acquiring additional knowledge and skills, obtaining lifelong learning services.

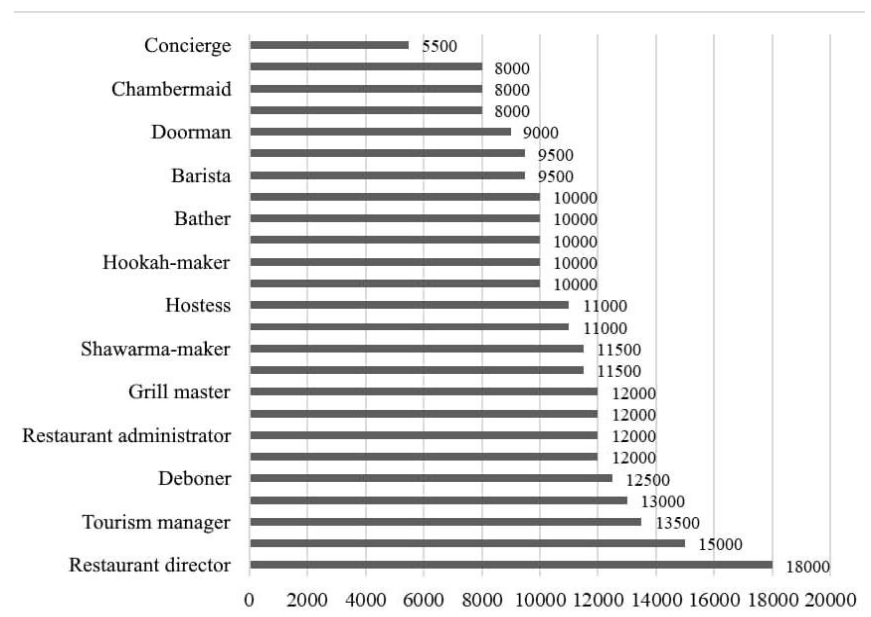

Figure 2. Distribution of wages (UAH) in the hotel and catering industry in Ukraine in 2019 (Source: Work.ua, 2020)

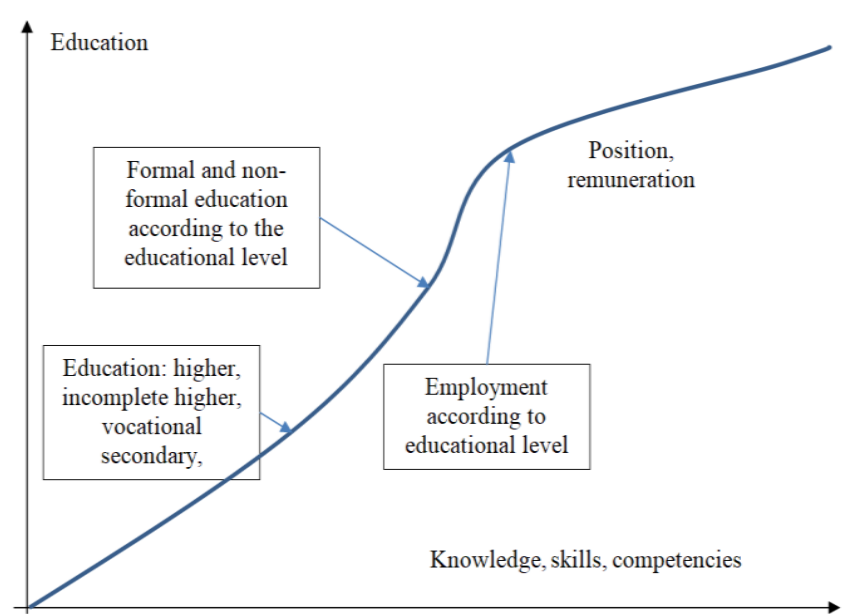

Figure 3. The life cycle of specialists in the hotel and catering industry in the context of lifelong learning (Source: compiled by the author)

Management staff and top management (operations director, restaurant manager) receive additional educational services in various areas of the hotel and catering industry, related to the management of various subsystems of the organization. For instance, heads of establishments of hospitality field receive informal and formal educational services for managing business processes in logistics, sales, marketing, finance, personnel management, security and information support. Top management specialist is a highly qualified specialist with salary requirements in the amount of $100000 \mathrm{UAH} / \mathrm{month}$, who has received higher education. Top management specialist should always systematically acquire new knowledge. Among the main trainings, seminars, additional training programs, the following ones should be highlighted: personnel management, time management, loyal customer, enterprise management, business economics, seminar of leading specialists of the corporation on catering industry and the art of personnel management; seminars and practical trainings by categories, namely: motivation and teamwork, personnel selection, quality service, planning, customer care, quality management process, organization of the learning process, administration, kitchen workflow organization, cost control, sanitation, warehouse accounting and cash discipline. Additional skills are as follows: professional computer and software skills, Google Adwords, fluency in 2-3 languages (mostly English, Russian). Another additional skills include: understanding business principles; ability to work independently; experience in information and communication management; excellent team building skills; accounting skills; work in a multitasking environment; great attention to detail; exceptional organizational skills; excellent communication skills; knowledge of business etiquette, constructive negotiations with partners and clients; presentation of the company at exhibitions; knowledge of Russian and American standards of service and doing business; project management; integration of international standards. Basic formal higher education in the field of hospitality is usually supplemented by higher education in management, economics and production management.

Middle managers have a lower level of qualifications, skills and work experience, received additional educational services in the field of hospitality compared to top-managers and managers. Middle managers are trained in related fields of knowledge or specialized informal courses, namely: features of national etiquette, "work in conflict conditions", "hospitality and service standards", video lectures on psychology. The life cycle of a specialist in the hotel and catering 
industry in the context of lifelong learning depends on the initial educational level, skills and competencies formed in the process of employment by profession, received additional educational services, trainings, seminars, courses of formal and informal educational institutions. The considered cases of experts testify to dependence of payment and level of qualification on technology of preparation (Figure 3). In general, the training technology consists of three components, namely: 1) formal educational training based on curricula for the selected level of specialization; 2) formal educational training based on educational programs (curricula) in an additional direction of training (management, enterprise economics, marketing); 3) informal training in the form of courses, seminars, short-term curricula, trainings.

The conducted research reveals another problem in the field of training specialists in the hotel and catering industry in the context of lifelong education: the life cycle of a specialist depends on the level of independence in managing his own development, development of skills and competencies. The need to support qualifications, a higher level of remuneration and the formation of skills in various management subsystems forces specialists to gain additional knowledge in logistics, personnel management, finance and accounting, project and team management, time management, psychology, enterprise management, high-quality service, planning, customer care, quality management process. In the practice of training there are significant differences that depend on the educational and qualification level. Whilst specialists with higher education hold managerial positions, then specialists with specialized education mostly hold the position of a chef, a middle manager. Top management specialist is responsible for the systemic process of lifelong learning for the development of management skills in various subsystems. For comparison, middle management specialist mainly passes one-time seminars (psychological trainings, trainings on stress resistance, specialized courses, certification trainings). Obtaining knowledge in formal education institutions is supplemented by formal/non-formal educational training programs in order to develop professional skills and competencies (Rangus et al., 2020). Workshops and internships are considered by students as an effective experimental approach to learning (LeBruto and Murray, 1994). Along with this, the professional activity of specialists is much less regulated and certified with an inconsistency of training methods and technologies. Lifelong courses are designed to train professionals in "laboratory" conditions (kitchens, restaurants, bars, reception rooms, apartments for living); herewith, technologies and training methods are often questionable (Tsai et al., 2020). At the same time, the research notes another problem - the inconsistency of training programs and practice in the field of hospitality. Training hotels are among the effective technologies and learning environments; however, scientists note the low level of academic orientation of this technology (King and Tang, 2020). This is due to the experimental nature of learning in real business conditions, such as training hotels in regions where educational services in the field of hospitality are expanding.

This research proves that the variability of the external environment in the hospitality industry due to increased competition leads to a constant systemic need for continuous knowledge support from employees and candidates throughout their lives. As a result, the labor market offers highly qualified professionals with additional skills and competencies. Over the last twenty years (since the early 2000s) (Christou and Sigala, 2001) the need for managerial competencies of employees in the hospitality industry, especially top management, has been studied. Research proves the relevance of this issue, forasmuch as managers in the field of hospitality receive additional knowledge throughout the life cycle in various fields in order to effectively manage. The differentiation of training requirements at the request of managers is also actively discussed in the scientific literature (Agut et al., 2003). This study suggests that the differentiation of requirements depends on the position and the problem situations faced by the manager in the hospitality industry. This determines his need for additional courses and seminars, trainings and educational programs in various areas. It also means the dependence of the need for training of the specialist's personal qualities. Research proves the lack of long-term interested parties' cooperation in the development of managers of hotel and catering industry (Littlejohn and Watson, 2004), forasmuch as employees are responsible for lifelong learning. In addition, there is no practice of implementing strategies for the professional development of personnel in the hospitality industry. It does not provide internationally regulated development of new learning technologies, distance learning, quality, personnel development, integration of innovative learning styles, and research in this area (Christou and Sigala, 2001). The strategy of professional development is completely individual; it depends on the motivation of the specialist and involves the implementation of only one component: formal and non-formal training after education. For this reason, this strategy does not respond to the challenge that is still relevant for 20 years - the need to develop personnel in one of the "low-skilled" sector of the economy hospitality industry (Baum, 2002). According to this study, the majority of specialists (over 60\%) are low-skilled, without work experience, internship, additional formal or informal training programs. This is due to both the lack of training practice for specialists at the expense of employers, and the low level of participation of specialists in additional educational programs, courses, seminars, trainings. That is why the issue of ensuring the integration of practical, pragmatic approaches to the development of technologies for basic training of professionals in hotel and catering industry in the context of lifelong learning should remain a priority for economic entities (Chalupa and Petricek, 2010); it should develop practical skills.

\section{CONCLUSION}

The conducted research makes it possible to draw a number of important conclusions. The technologies for training specialists in the hotel and catering industry in the context of lifelong learning differ significantly within EU countries. In particular, there are differences in such characteristics as the provider of educational services, the initial level of education, the position held by the specialist and the status in the society. Non-formal education is the main way and form of acquiring new knowledge, which prevails in all EU countries. In Ukraine, students in the hotel and catering industry face the problem of hiring because of the absence of experience. The technologies for training specialists in the hotel and catering industry in Ukraine in the context of lifelong education differ significantly depending on the position, 
work experience, knowledge of foreign languages, education, professional skills. However, the determining conditions for lifelong learning in this area are the level of education, previous job and experience, as well as the position. It is these characteristics that determine the ability to train a specialist throughout life. In general, the training technology consists of three components, namely: formal educational training based on curricula at the selected level of specialization; formal educational training on the basis of educational programs (curricula) in an additional area of training (management, business economics, marketing); informal training in the form of courses, seminars, short-term training programs, trainings.

\section{REFERENCES}

Agut, S., Grau, R., \& Peiró, J.M. (2003). Competency needs among managers from Spanish hotels and restaurants and their training demands. International Journal of Hospitality Management, 22(3), 281-295. https://doi.org/10.1016/S0278-4319(03)00045-8

Ballesteros-Rodríguez, J.L., De Saá-Pérez, P., \& Domínguez-Falcón, C. (2012). The role of organizational culture and HRM on training success: evidence from the Canarian restaurant industry. The International Journal of Human Resource Management, 23(15), 32253242. https://doi.org/10.1080/09585192.2011.637071

Baum, T. (2002). Skills and training for the hospitality sector: a review of issues. Journal of vocational Education and Training, 54(3), 343-364. https://doi.org/10.1080/13636820200200204

Brahami, M., Adjaine, M., Semaoune, K., \& Matta, N. (2020). The influences of knowledge management and customer relationship management to improve hotels performance: a case study in hotel sector. Information Resources Management Journal, 33(4), 74-93. http://dx.doi.org/10.4018/IRMJ.2020100105

Chalupa, S., \& Petricek, M. (2020). The application of business process management in the hospitality industry: A case study. IBIMA Business Review, 1(301930), 1-11. http://dx.doi.org/10.5171/2020.301930

Christou, E., \& Sigala, M. (2001). Professional development in hospitality and tourism education: A strategy for the 21st century. The International Journal of Tourism Research, 3(4), 328-335. http://dx.doi.org/10.1002/jtr.317

Clarke, N. (2002). Job/work environment factors influencing training transfer within a human service agency. International Journal of Training and Development, 6(3), 146-162. http://dx.doi.org/10.1111/1468-2419.00156

El-Said, O.A., Al Hajri, B., \& Smith, M. (2020). An empirical examination of the antecedents of training transfer in hotels: the moderating role of supervisor support. International Journal of Contemporary Hospitality Management, 32(11), $3391-3417$. http://dx.doi.org/10.1108/IJCHM-04-2020-0262

Frash, R., Antun, J., Kline, S., \& Almanza, B. (2010). Like it! Learn it! Use it? A field study of hotel training. Cornell Hospitality Quarterly, 51(3), 398-414. http://dx.doi.org/10.1177/1938965510364931

Holton, E.F., Bates, R.A., \& Ruona, W.E. (2000). Development of a generalized learning transfer system inventory. Human Resource Development Quarterly, 11(4), 333-360. http://dx.doi.org/10.1002/1532-1096(200024)11:4\%3C333::AID-HRDQ2\%3E3.0.CO;2-P

Jaswal, H.S. (2020). Changing perception of students towards hotel management course while pursuing the course. European Journal of Molecular and Clinical Medicine, 7(7), 2975-2982. https://ejmcm.com/article_5002.html

LeBruto, S.M., \& Murray, K.T. (1994). The educational value of "Captive Hotels". The Cornell Hotel and Restaurant Administration Quarterly, 35(4), 72-79. https://doi.org/10.1016/0010-8804(94)90096-5

Leslie, D., \& Richardson, A. (2000). Tourism and cooperative education in UK undergraduate courses: are the benefits being realized? Tourism Management, 21(5), 489-498. https://doi.org/10.1016/S0261-5177(99)00103-X

Littlejohn, D., \& Watson, S. (2004). Developing graduate managers for hospitality and tourism. International Journal of Contemporary Hospitality Management, 16(7), 408-414. https://doi.org/10.1108/09596110410559096

Kalargyrou, V., \& Woods, R.H. (2011). Wanted: training competencies for the twenty-first century. International Journal of Contemporary Hospitality Management, 23(3), 361-376. http://dx.doi.org/10.1108/09596111111122532

King, B., \& Qiu, H. (2017). Experiential tourism and hospitality learning: principles and practice. In: Benckendorff, P., Zehrer, A. (Eds.), International Handbook of Teaching and Learning in Tourism. Edward Elgar, Northampton, UK, pp. 207-217.

King, B., \& Tang, C.M.F. (2020). Training hotels in Asia: an exploration of alternative models. Journal of Hospitality \& Tourism Education, 32(1), 43-54. https://doi.org/10.1080/10963758.2019.1654883

Koo, G., Lee, N., \& Kwon, O. (2019). Combining object detection and causality mining for efficient development of augmented realitybased on-the-job training systems in hotel management. New Review of Hypermedia and Multimedia, 25(3), $112-136$. https://doi.org/10.1080/13614568.2019.1694594

Olsen, M.D., \& Connolly, D.J. (2000). Experience-based travel: how technology is changing the hospitality industry. Cornell Hotel and Restaurant Administration Quarterly, 41(1), 30-40. https://doi.org/10.1016/S0010-8804(00)88883-7

Osypova, I.I. (2020). Labor force of Ukraine 2019. Statistical compilation. State Statistics Service of Ukraine, Ukraine.

Rakicevik, G., Miladinoski, S., \& Strezoska, J. (2008). Lifelong learning in restaurant business. Tourism and Hospitality Management, 14(1), 105-114. https://hrcak.srce.hr/181052

Rangus, M., Radenković-Šošić, B., Milošević, S., Hočevar, J., Škrbić, I., \& Knežević, M. (2020). Professional and organisational commitment in the hospitality sector. Academica Turistica, 13(2), 179-191. http://dx.doi.org/10.26493/2335-4194.13.179-191

Ruhanen, L. (2006). Bridging the divide between theory and practice: experiential learning approaches for tourism and hospitality management education. Journal of Teaching in Travel \& Tourism, 5(4), 33-51. https://doi.org/10.1300/J172v05n04_03

Scerri, M., Presbury, R., \& Goh, E. (2020). An application of the mentoring framework to investigate the effectiveness of mentoring programs between industry mentors and student mentees in hospitality. Journal of Hospitality and Tourism Management, 45, 143151. https://doi.org/10.1016/j.jhtm.2020.08.010

Tsai, C.H., Linliu, S.C., Chang, R.C.Y., \& Mak, A.H.N. (2020). Disaster prevention management in the hotel industry: hotel disaster prevention literacy. Journal of Hospitality and Tourism Management, 45, 444-445. https://doi.org/10.1016/j.jhtm.2020.09.008

Tse, T.S.M. (2012). The experience of creating a teaching hotel: a case study of Hotel Icon in Hong Kong. Journal of Hospitality \& Tourism Education, 24(1), 17-25. http://dx.doi.org/10.1080/10963758.2012.10696658

*** Eurostat (2020a). Distribution of non-formal education and training activities by provider. https://appsso.eurostat.ec.europa.eu/ nui/setupDownloads.do

*** Eurostat (2020b). Distribution of education and training activities by field (ISCED-F 2013).: https://data.europa.eu/euodp/en/data/ dataset/lm3WJLDvmFwbOQgAdcXVtw

*** Work.ua (2020). Average salary for the category "Hotel and restaurant business, tourism” in Ukraine. https://www.work.ua/salaryhotel-restaurant-tourism/?page $=2$ 